\title{
Influence of model resolution on the atmospheric transport of ${ }^{10} \mathrm{Be}$
}

\author{
U. Heikkilä and A. M. Smith \\ Australian Nuclear Science and Technology Organisation (ANSTO), New Illawarra Road, Lucas Heights, NSW 2234, \\ Australia \\ Correspondence to: U. Heikkilä (ulla@ansto.gov.au)
}

Received: 22 June 2012 - Published in Atmos. Chem. Phys. Discuss.: 30 July 2012

Revised: 7 November 2012 - Accepted: 7 November 2012 - Published: 13 November 2012

\begin{abstract}
Understanding the transport path of the solar activity proxy ${ }^{10} \mathrm{Be}$ from source to archive is crucial for the interpretation of its observed variability. The extent of mixing of the strong production signal has been quantified in a previous study (Heikkilä et al., 2009). In this study we perform sensitivity studies to investigate the influence of model resolution on the degree of mixing and transport path of ${ }^{10} \mathrm{Be}$ in the atmosphere using the ECHAM5-HAM aerosol-climate model. This study permits us to choose an acceptable resolution, and so minimum CPU time, to produce reconstructions as physically accurate as possible. Five model resolutions are applied: T21L19: a coarse horizontal and vertical resolution with model top at ca. $30 \mathrm{~km}, \mathrm{~T} 42 \mathrm{~L} 31$ : an average horizontal and fine vertical one, T42L39: similar vertical resolution than L19 but including the middle atmosphere up to ca. $80 \mathrm{~km}$, T63L31: a fine horizontal and vertical resolution and T63L47: a fine resolution horizontally and vertically with middle atmosphere. Comparison with observations suggests that a finer horizontal and vertical resolution might be beneficial, producing a reduced meridional gradient, although the spread between observations was much larger than between the five model runs. In terms of atmospheric mixing the differences became more distinguishable. All resolutions agreed that the main driver of deposition variability, observed in natural archives, is the input of stratospheric ${ }^{10} \mathrm{Be}$ (total contribution $68 \%$ ) which is transported into the troposphere at latitudes $30-50^{\circ}$. In the troposphere the model resolutions deviated largely in the dispersion of the stratospheric component over latitude. The finest resolution (T63L47) predicted the least dispersion towards low latitudes but the most towards the poles, whereas the coarsest resolution (T21L19) suggested the opposite. The tropospheric components of ${ }^{10} \mathrm{Be}$ differed less between the five model runs. The largest differences were found in the polar
\end{abstract}

tropospheric components, which contribute the least to total production $(\approx 4 \%)$. We conclude that the use of the T42 horizontal resolution seems to be sufficient in terms of atmospheric mixing of a stratospheric tracer because no substantial improvement was seen when the resolution was increased from T42 to T63. The use of the middle atmospheric configuration is a trade-off between correctly describing stratospheric dynamics and having to reduce vertical resolution. The use of a high vertical resolution seemed more beneficial than the middle atmospheric configuration in this study. The differences found between the T42L31 and T63L31 resolutions were so small that T42L31 is a good choice because of its computational efficiency.

\section{Introduction}

Cosmogenic radionuclides, such as ${ }^{10} \mathrm{Be}$ (half-life 1.4 million years) and ${ }^{7} \mathrm{Be}$ (half-life 53.2 days), are commonly used proxies for past cosmic ray intensity and solar activity. They are produced in the atmosphere by primary and secondary particles of cosmic rays (protons and neutrons) interacting with atmospheric nitrogen and oxygen atoms. The intensity of cosmic rays in the atmosphere is modulated by solar and geomagnetic activity and hence observed variations of cosmogenic radionuclide concentrations in natural archives, such as ice cores, can be used to reconstruct cosmic ray intensity in the past. After production, ${ }^{10} \mathrm{Be}$ and ${ }^{7} \mathrm{Be}$ atoms attach to ambient aerosol, mainly sulfate, and are transported through the atmosphere and deposited to natural archives with them.

Modelling the atmospheric transport of beryllium isotopes is a difficult task. Their main source in the stratosphere (e.g. Lal and Peters, 1967) and long residence time 
in the atmosphere (approx. 1 yr e.g. Pedro et al., 2011) require the use of a global model or at least one including one hemisphere. Comparison with observations has shown that they are much more sensitive to uncertainties in scavenging and atmospheric transport than short-lived tracers emitted from Earth's surface (Brost et al., 1996; Koch et al., 2006; Liu et al., 2001). Optimally a model version including the middle atmosphere would be used, describing full stratospheric dynamics and allowing for a better representation of the Brewer-Dobson circulation and hence tracer transport. These factors add to the cost of model simulations and prohibit the use of a high resolution. Yet the observations, mostly surface air concentrations or deposition fluxes, are strongly influenced by small scale atmospheric processes, such as precipitation rate or intrusions of stratospheric air into the troposphere. Regional or particle dispersion models can be employed for investigating individual processes but their contribution to total transport, including large scale, and deposition is hard to estimate because the background is not known. Finally the limited temporal and spatial coverage of observations complicates a full validation of model results.

Thankfully the temporal resolution of observations, such as ice cores, is relatively coarse which averages out much of the small scale variability. Due to the stratospheric origin of ${ }^{10} \mathrm{Be}$ an important driver for long term variability is large scale transport, mainly the location of stratospheretroposphere exchange. The important issue in correctly associating the observed ${ }^{10} \mathrm{Be}$ variations to solar activity is to understand the level of mixing of ${ }^{10} \mathrm{Be}$ in the atmosphere. As the solar and geomagnetic modulation of the ${ }^{10} \mathrm{Be}$ production rate varies largely in amplitude with altitude and latitude it is crucial to understand which source region ${ }^{10} \mathrm{Be}$ in natural archives represents.

One previous study has addressed the atmospheric mixing, quantifying the fractions of ${ }^{10} \mathrm{Be}$ produced in a given part of the atmosphere and where it is deposited (Heikkilä et al., 2009). These results were based on one model realisation only. The aim of the present study is to investigate how reproducible the results are using another model version and a different computer environment, as well as the influence of model resolution. Ideally another aerosol-climate model would be employed for a similar study to address the model dependency as well. We apply model resolutions varying from a very coarse to a fine one. Also the influence of including the entire stratosphere into the model (middleatmosphere configuration) is investigated.

The impact of model resolution on middle atmosphere dynamics and stratosphere-troposphere exchange, as well as climate in general, has previously been investigated by e.g. Gray (2003); Hack et al. (2006); Richter et al. (2008); van Velthoven and Kelder (1996), and in the ECHAM4/5 model specifically by Aghedo et al. (2010); Land et al. (2002); Roeckner et al. (2006). These studies used idealised passive tracers in combination with the ECHAM atmospheric model only. They agree that, in general, increasing vertical resolution decreases the strength of stratosphere-troposphere exchange and increases residence time of stratospheric particles. In addition, Aghedo et al. (2010) shows that increased vertical transport at a coarse resolution leads to a decreased meridional transport of surface tracers. Roeckner et al. (2006) performed a careful validation of sensitivity of model climate to resolution against the ERA-40 reanalysis. They show that the error generally reduces when resolution is increased. However, both horizontal and vertical resolution have to be chosen consistently. Correct representation of the stratosphere-troposphere exchange is of essential importance in order to quantify the distribution between the source and the sink regions of beryllium isotopes and associate variability observed in a natural archive to atmospheric production variability and hence solar activity.

\section{Method}

The model employed for this study is the ECHAM5 general circulation model of the atmosphere (Roeckner et al., 2003) coupled with the aerosol module HAM (Stier et al., 2005). The HAM module describes the emission, physics, chemistry and deposition of aerosol. The beryllium isotopes $\left({ }^{10} \mathrm{Be}\right.$ and ${ }^{7} \mathrm{Be}$ ) have been implemented into the model including their production rate following Masarik and Beer (2009) interpolated to the monthly varying solar activity parameter $\Phi$, transport and deposition and, in the case of ${ }^{7} \mathrm{Be}$, its radioactive decay. Details of the implementation of all these processes are given in Heikkilä et al. (2008b). The model was forced with observed sea-surface temperatures and seaice cover (AMIP2). The model experiments were run for 10 years (1993-2002). The first five years were required to let ${ }^{10} \mathrm{Be}$ reach equilibrium and discarded. The following five years (1998-2002) were used for the analysis.

The model resolution used in previous beryllium modelling studies using the ECHAM5-HAM has been a compromise between a high-enough resolution and a reasonable runtime. ECHAM is often run as a climate or an aerosol model at a higher horizontal resolution (T63 or T106) with a relatively limited number of vertical levels (19 or 31) (e.g. Hagemann et al., 2006; Stier et al., 2005). This is a suitable approach when modelling climate or short lived particles emitted from the surface which rarely make it to the stratosphere. Therefore, first modelling studies of beryllium isotopes were conducted using 31 vertical levels and the model top at ca. $30 \mathrm{~km}$ (T42L31, Heikkilä et al., 2008b). Later it was reasoned that allowing for a better representation of stratospheric dynamics would improve the beryllium transport in the model (T42L39, model top at $80 \mathrm{~km}$ Heikkilä et al., 2009). This, however, happened at the cost of the vertical resolution at lower levels because the total number of levels increased only marginally. For this study we chose five different combinations of horizontal and vertical resolutions: (1) A coarse resolution (T21L19, ca. $626 \mathrm{~km}$ horizontally (at 
Table 1. Details of model resolutions (horizontal and vertical) used in this study

\begin{tabular}{lccccc}
\hline & T63L47 & T63L31 & T42L31 & T42L39 & T21L19 \\
\hline horiz. grid $\left({ }^{\circ}\right)$ & 1.875 & 1.875 & 2.813 & 2.813 & 5.625 \\
horiz. grid $(\mathrm{km})$ & 209 & 209 & 313 & 313 & 626 \\
time step $(\mathrm{min})$ & 15 & 15 & 24 & 24 & 40 \\
model top $(\mathrm{km})$ & $\approx 80$ & $\approx 30$ & $\approx 30$ & $\approx 80$ & $\approx 30$ \\
vertical levels & 47 & 31 & 31 & 39 & 19 \\
\hline
\end{tabular}

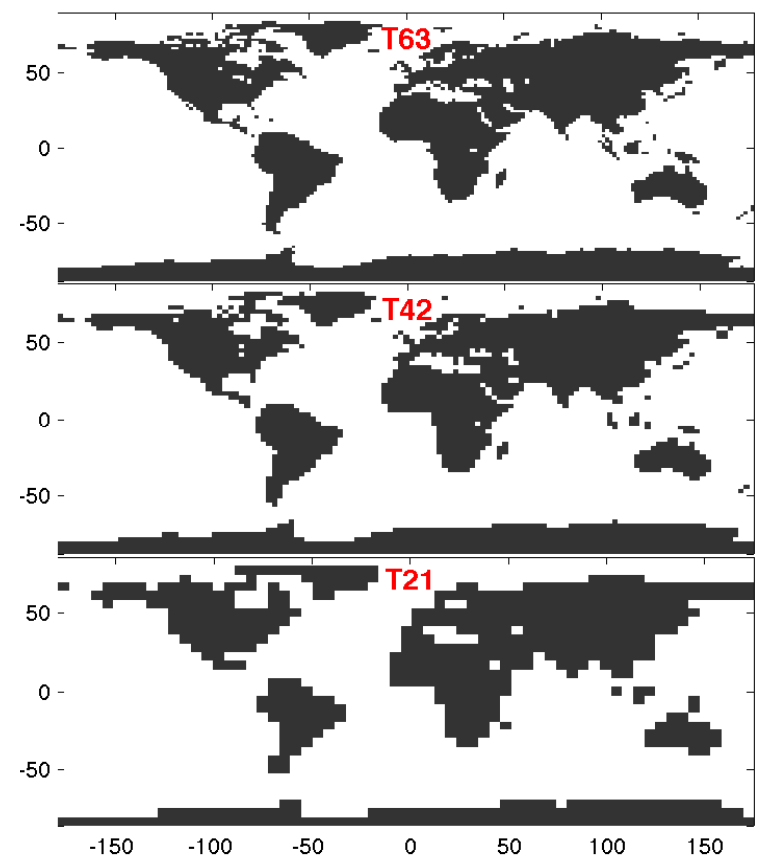

Fig. 1. Model coastline at horizontal resolutions used in this study: $209 \mathrm{~km}$ at Equator (T63), $313 \mathrm{~km}$ (T42) and $626 \mathrm{~km}$ (T21).

Equator) with 19 vertical levels up to ca. $30 \mathrm{~km}$ ). We wanted to test the influence of a coarse horizontal resolution on the horizontal diffusion of atmospheric particles. (2) An average horizontal and high vertical resolution typically used for ${ }^{10} \mathrm{Be}$ studies (T42L31, ca. $313 \mathrm{~km}$ horizontally with 31 vertical levels up to ca. $30 \mathrm{~km}$ ), (3) An average horizontal and coarse vertical one but including the whole stratosphere (T42L39, $313 \mathrm{~km}$ horizontally with 39 levels up to ca. $80 \mathrm{~km}$. This vertical resolution is similar to L19 up to $30 \mathrm{~km}$ ), (4) A fine horizontal and vertical resolution (T63L31, $209 \mathrm{~km}$ horizontally and 31 vertical levels up to ca. $30 \mathrm{~km}$ ) and (5) A fine resolution, including the whole stratosphere (T63L47, $209 \mathrm{~km}$ horizontally with 47 vertical levels up to $80 \mathrm{~km}$ ). Correspondingly, this resolution is comparable with the L31 at lower levels. T63L47 was pushing towards the limit of computational cost of our simulations prohibiting its use for long experiments. The model coastline, as described by the various horizontal resolutions, is shown in Fig. 1. A summary of the resolutions used is given in Table 1.
In order to study the transport path of beryllium atoms from their source in the stratosphere until their deposition the production rates were divided into 30-degree latitude bands in the stratosphere and the troposphere, following Heikkilä et al. (2009). The sum of all these atmospheric compartments gave the total production. The model defined tropopause was used as the vertical limiter between the stratosphere and the troposphere. Hence we ended up with 6 compartments in both the troposphere and the stratosphere $\left(60-90^{\circ} \mathrm{S}, 30\right.$ $60^{\circ} \mathrm{S}, 0-30^{\circ} \mathrm{S}, 0-30^{\circ} \mathrm{N}, 30-60^{\circ} \mathrm{N}$ and $\left.60-90^{\circ} \mathrm{N}\right) .{ }^{10}$ Be produced in each of these compartments was defined as a separate tracer, allowing for a quantification of where ${ }^{10} \mathrm{Be}$, produced in a given atmospheric region, was deposited. Air concentrations also show the transport from source at each model level, not only at sink such as deposition flux. Please note that all particles were simulated as individual atoms in the model and the fluxes shown throughout the manuscript show the number of atoms per meter squared and time unit, and are directly comparable with atoms measured in natural archives.

In order to validate the transport of atmospheric particles by the model the additional tracer ${ }^{210} \mathrm{~Pb}$ was implemented into the model. ${ }^{210} \mathrm{~Pb}$ is often measured in the same samples as ${ }^{7} \mathrm{Be}$ and a reasonably large number of observations exist. ${ }^{210} \mathrm{~Pb}$ is a decay product of ${ }^{222} \mathrm{Rn}$ which is emitted from porous soil containing uranium. ${ }^{222} \mathrm{Rn}$ (half-life 3.8 days) rapidly decays into ${ }^{210} \mathrm{~Pb}$ which thus has its source in the lower troposphere over continents. Because the actual emission distribution of ${ }^{222} \mathrm{Rn}$ is complex and not well known we adapt a simplified emission scheme of 1 atom $\mathrm{cm}^{-2} \mathrm{~s}^{-1}$ over continents, reduced to 0.33 atom $\mathrm{cm}^{-2} \mathrm{~s}^{-1}$ under freezing conditions or on ice covered surfaces. This simplified emission scheme has successfully been used by numerous modelling studies (e.g. Feichter et al., 1991; Liu et al., 2001; Koch et al., 2006). ${ }^{210} \mathrm{~Pb}$ has a similar geochemical behaviour to ${ }^{10} \mathrm{Be}$ or ${ }^{7} \mathrm{Be}$. After production it quickly attaches to ambient aerosol and undergoes the same transport and deposition. ${ }^{7} \mathrm{Be}$ has its main source in the stratosphere and a long atmospheric residence time whereas ${ }^{210} \mathrm{~Pb}$ is produced close to surface and removed rapidly, but both are deposited in a similar way. Hence the comparison of both serves to probe the vertical transport predictions of the models. 


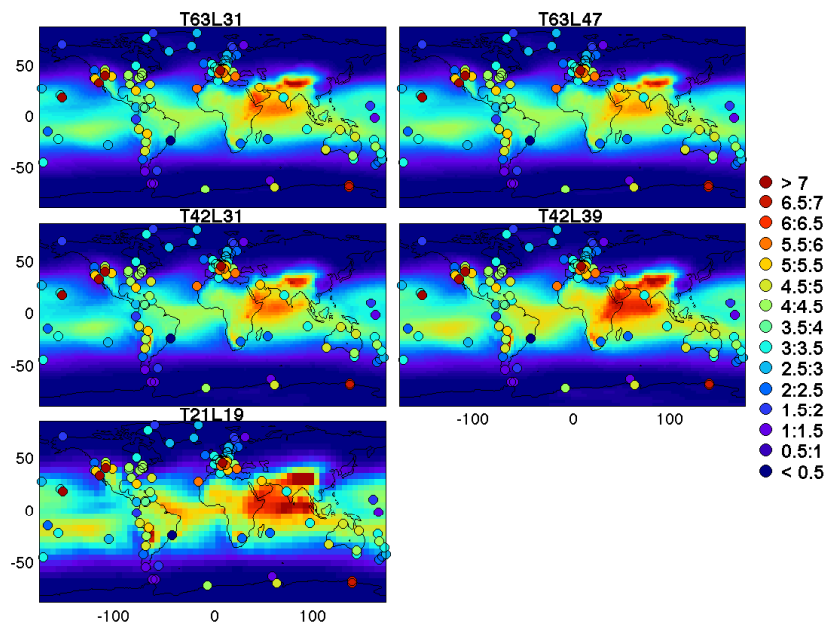

Fig. 2. 1998-2002 mean surface air concentration of ${ }^{7} \mathrm{Be}$ $\left(\mathrm{mBq} \mathrm{m}^{-3} \mathrm{STP}\right)$ with different model resolutions. The dots show the location and observed concentration of the measurement stations (references given in the text).

\section{Model validation}

\subsection{Surface air concentrations}

First we would like to investigate whether the use of a higher model resolution actually improves the model performance in terms of reproducing observations. Our validation is based on ${ }^{7} \mathrm{Be}$ and ${ }^{210} \mathrm{~Pb}$ due to a larger availability of data. ${ }^{7} \mathrm{Be}$ is being observed in various monitoring networks worldwide and offers a reasonably well distributed set of data. We use the observations of the Environmental Measurement Laboratory (EML: http://www.nbl.doe.gov/ htm/EML_Legacy_Website/index.htm) combined with other studies (Al-Azmi et al., 2001; Cannizzaro et al., 2004; Elsässer et al., 2011; Gerasopoulos et al., 2001; Kulan et al., 2006; Pacini et al., 2011; Papastefanou and Ioannidou, 1996). This way we obtained $109{ }^{7} \mathrm{Be}$ and $51{ }^{210} \mathrm{~Pb}$ observations. The temporal coverage of the observations is not consistent. Most data are long term means but some might only cover a few years. The years observed rarely coincide with each other or the modelled period. The locations of the stations are shown in Fig. 2. The spatial coverage of the stations is relatively good but still large areas in Asia, most of Africa, eastern Latin America, North Atlantic and the Southern Ocean lack observations. Figure 2 illustrates the ${ }^{7} \mathrm{Be}$ model predictions and the colour of the dots indicates the observed concentrations. The figure also illustrates the 5 -year mean ${ }^{7} \mathrm{Be}$ concentrations in the lowest model level.

The model successfully reproduces higher observed concentrations at low latitudes and lower concentrations at high latitudes. There is an abundance of observations in Europe and North America, the highest values (5$6 \mathrm{mBq} \mathrm{m}^{-3} \mathrm{STP}=$ standard temperature $(273.15 \mathrm{~K})$ and pres-

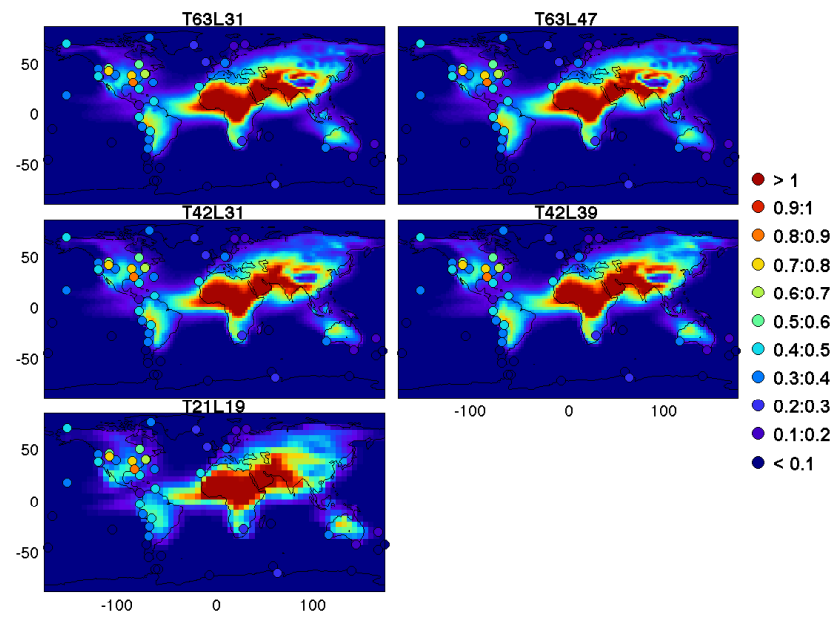

Fig. 3. 1998-2002 mean surface air concentration of ${ }^{210} \mathrm{~Pb}(\mathrm{mBq}$ $\mathrm{m}^{-3}$ STP) with different model resolutions. The dots show the location and observed concentration of the measurement stations (references given in the text).

sure $(1013.25 \mathrm{hPa}))$ being observed in the mountains. The concentrations in the lowlands are typically $1-3 \mathrm{mBq} \mathrm{m}^{-3}$. The model does not reproduce the highest values because the mountains are not resolved even at T63 resolution. Otherwise the model tends to be on the lower side of the observed variability but generally within a factor of 2 of observations.

There is some discrepancy between model and observations on oceanic islands, as well as in Antarctica. The observations on the islands are often taken at high altitude stations. This is a challenge for the model as the resolution is not sufficient to even resolve the islands, let alone to represent the high altitude (see Fig. 1). To account for this, the value at a model level corresponding to the altitude in question is shown later in Fig. 7. There are large variations between the concentrations observed on the Antarctic coast. The model results are consistent with the lower ones but underestimates the values exceeding $4 \mathrm{mBq} \mathrm{m}^{-3}$. Generally the observations vary largely in space whereas the model simulates a smooth field with only small changes in the zonal direction. All resolutions produce very similar fields. The main difference found is between the coarse and fine vertical resolutions. The coarser ones produce higher concentrations in the tropics, especially over Himalaya, Middle East, India and the Indian ocean. The few observations in that area suggest that the model has too large a meridional gradient which is reduced in the simulations with a higher horizontal resolution (T63L47 and T63L31) but this should be confirmed by a larger number of observations.

In the case of ${ }^{210} \mathrm{~Pb}$ (Fig. 3) the differences between model resolutions are insignificant. The general observed distribution of high concentrations over continents and lower ones far from the sources of ${ }^{222} \mathrm{Rn}$ is well reproduced by the model. Solely in North America the model fails to reproduce 


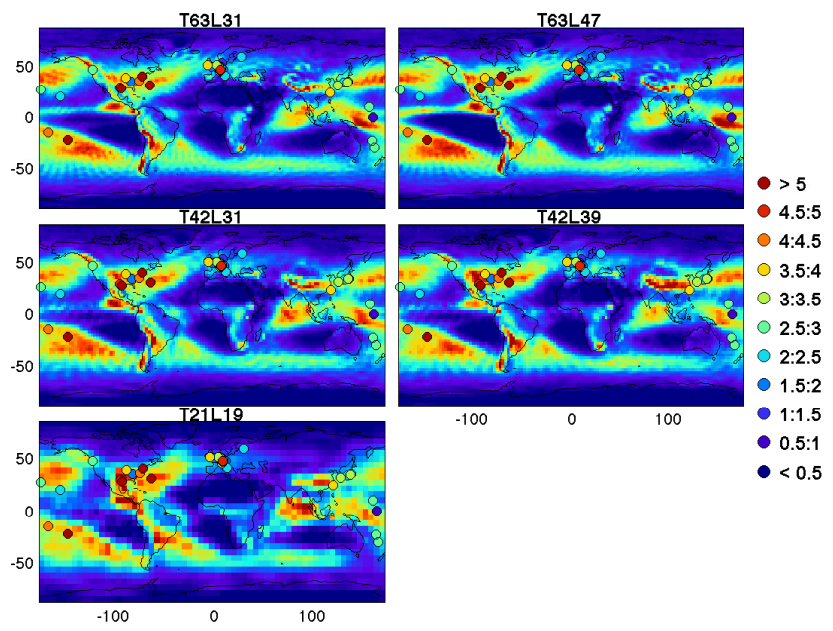

Fig. 4. 1998-2002 mean deposition flux of ${ }^{7} \mathrm{Be}$ atoms $\left(100 \mathrm{~m}^{-2}\right.$ $\mathrm{s}^{-1}$ ) with different model resolutions. The dots show the location and observed deposition flux of the measurement stations (references given in the text).

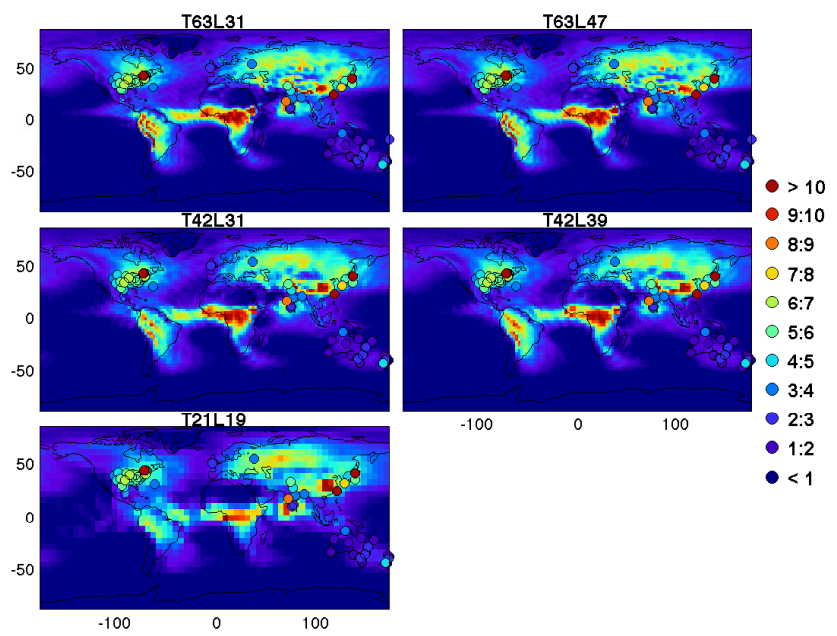

Fig. 5. 1998-2002 mean deposition flux of ${ }^{210} \mathrm{~Pb}$ atoms $\left(1000 \mathrm{~m}^{-2}\right.$ $\mathrm{s}^{-1}$ ) with different model resolutions. The dots show the location and observed deposition flux of the measurement stations (references given in the text).

some of the observed high values. In the areas where highest values are modelled (North Africa, Middle East and India) no observations are available. This highlights how it is relatively simple to model a short lived surface tracer. A stratospheric tracer, such as ${ }^{7} \mathrm{Be}$, reveals differences between model resolutions and how they capture the vertical transport of atmospheric particles. However, more observations are required to make full use of this test.

\subsection{Deposition fluxes}

To evaluate the model results in reproducing observed deposition fluxes we use all modern ${ }^{7} \mathrm{Be},{ }^{210} \mathrm{~Pb}$ and ${ }^{10} \mathrm{Be}$ fluxes

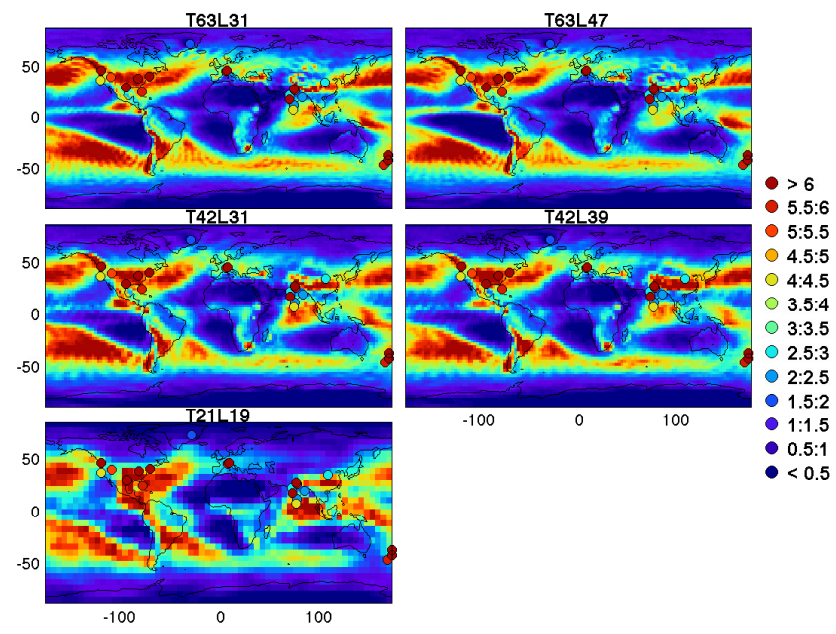

Fig. 6. 1998-2002 mean deposition flux of ${ }^{10} \mathrm{Be}$ atoms $\left(100 \mathrm{~m}^{-2}\right.$ $\mathrm{s}^{-1}$ ) with different model resolutions. The dots show the location and observed deposition flux at 21 stations (references given in the text).

found in the literature. The temporal coverage is often shorter (from a few months to $8 \mathrm{yr}$ ) than in the case of surface air concentrations and a much more limited number of observations is available. We simply average over whatever period the observations cover and compare them with the modelled 5-yr mean fluxes. There are ${ }^{7} \mathrm{Be}$ observations from 37 stations (Baskaran et al., 1993; Bleichrodt, 1978; Brown et al., 1988; Crecelius, 1981; Hasebe et al., 1981; Heikkilä et al., 2008a; Hirose et al., 2004; Huh et al., 2006; Igarashi et al., 1998; Knies, 1994; McNeary and Baskaran, 2003; Olsen et al., 1985; Todd et al., 1989; Turekian et al., 1983; Uematsu et al., 1994; Young and Silker, 1980), ${ }^{210} \mathrm{~Pb}$ from 71 stations (Baskaran et al., 1993; Graustein and Turekian, 1986; Huh et al., 2006; Hirose et al., 2004; McNeary and Baskaran, 2003; Nijampurkar and Clausen, 1990; Todd et al., 1989; Turekian et al., 1977, 1983) and ${ }^{10}$ Be from 21 stations (Chengde et al., 1992; Graham et al., 2003; Heikkilä et al., 2008a; Monaghan et al., 1986; Somayulu et al., 1984). The modelled 5yr mean deposition fluxes of ${ }^{7} \mathrm{Be},{ }^{10} \mathrm{Be}$ and ${ }^{210} \mathrm{~Pb}$ are shown in Figures 4, 5 and 6, together with the location and measured flux of the observations. A scatter plot of these results with correlation and root mean squared error (RMSE) is presented in Fig. 7. In areas with a dense coverage of stations (Europe and North America) the observations exhibit large variability. Again, the modelled fields are smoother and do not resolve the effect of mountains or small islands. Deposition fields are largely influenced by precipitation which is orographically increased at high altitudes. Due to this and the higher beryllium content in upper levels higher ${ }^{10} \mathrm{Be}$ and ${ }^{7} \mathrm{Be}$ fluxes are observed in mountainous areas (e.g. Heikkilä et al., 2008a; Huh et al., 2006). The modelled ${ }^{210} \mathrm{~Pb}$ deposition flux also seems to agree well with observations, successfully reproducing the high observed values over the continents in 


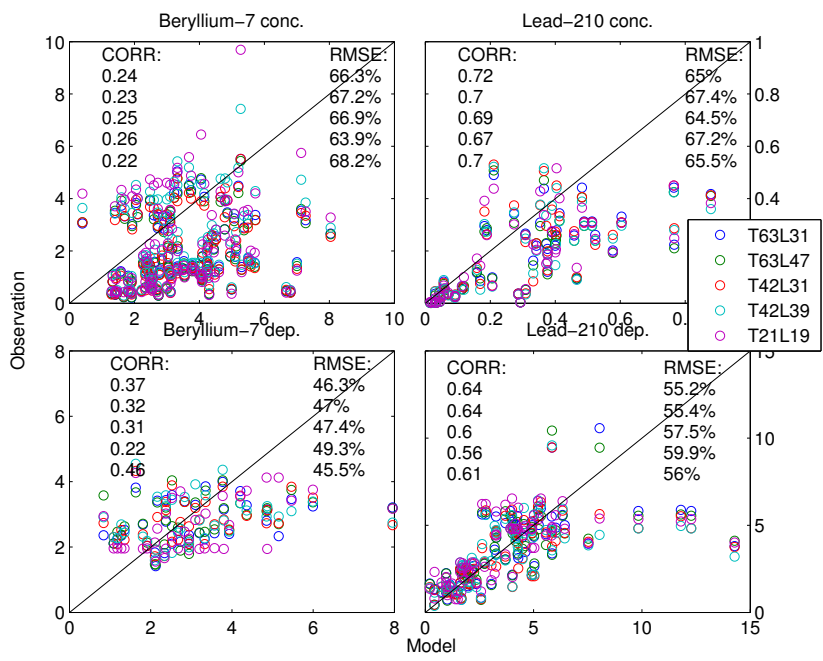

Fig. 7. Scatter plot of modelled versus observed 1998-2002 mean ${ }^{7} \mathrm{Be}$ and ${ }^{210} \mathrm{~Pb}$ surface air concentrations $\left(\mathrm{mBq} \mathrm{m}^{-3} \mathrm{STP}\right)$ and deposition flux of ${ }^{7} \mathrm{Be}$ atoms $\left(100 \mathrm{~m}^{-2} \mathrm{~s}^{-1}\right)$ and ${ }^{210} \mathrm{~Pb}$ atoms $\left(1000 \mathrm{~m}^{-2} \mathrm{~s}^{-1}\right)$ with different model resolutions. Correlation coefficients and root mean squared errors are also shown for each resolution, in the order indicated in the legend.

the Northern Hemisphere and the lower ones in the Southern Hemisphere.

The precipitation rate simulated by the different model resolutions also shows relatively little differences. We refer to Hagemann et al. (2006) for a full evaluation of the model performance in reproducing observed precipitation and limit our comments to the precipitation influence on particle deposition. The main difference found between resolutions is the band of high precipitation in the tropical Pacific which is only simulated by the highest resolution model (T63L47, not shown). It is consistent with the increase in ${ }^{7} \mathrm{Be}$ and ${ }^{10} \mathrm{Be}$ deposition. Also the ${ }^{7} \mathrm{Be}$ flux in the subtropical Pacific is increased with the higher vertical resolutions (T63L47 and T42L31) which can partly be seen in the precipitation rate as well. This is less obvious from the ${ }^{10} \mathrm{Be}$ deposition flux. As there are no stations in those areas we cannot assess which one of the resolutions is performing best.

The model seems to capture the overall magnitude of the observed deposition fluxes (see Figs. 4 and 7) which gives us confidence that the source strength is correct. Comparison with surface air concentrations gives an indication of the scavenging efficiency of aerosol in the model, especially in the case of ${ }^{7} \mathrm{Be}$. Although observations at nearby stations fall within a large range which the model is not able to capture the overall magnitude is well reproduced giving confidence that the scavenging efficiency and hence the atmospheric (especially tropospheric) residence time of beryllium isotopes is correct. Generally the differences between the model resolutions are smaller than the spread of observations from nearby areas. More observations with a denser spatial coverage are required to evaluate the performance of the different model resolutions. Another useful test would be to increase the model resolution (e.g. employing regional models) to see whether such a model reproduces the large spatial variability of the observations.

In order to quantify these findings a scatter plot of observed versus modelled values of ${ }^{7} \mathrm{Be}$ and ${ }^{210} \mathrm{~Pb}$ surface air concentrations and deposition fluxes are shown in Fig. 7, together with correlation coefficients and root-mean-squared errors ("RMSE"). Due to the limited number of ${ }^{10} \mathrm{Be}$ observations it is not shown in the scatter plot, but the results were similar to ${ }^{7} \mathrm{Be}$ and ${ }^{210} \mathrm{~Pb}$. If the altitude of the observation was high, concentration from a corresponding model layer was used instead of the surface value for this analysis. Obviously the differences between tracers are much more significant than differences between model resolutions. Both ${ }^{7}$ Be concentration (0.2-0.3) and deposition flux (0.3-0.4) exhibit low spatial correlation between model and observation, reflecting the difficulty in capturing the large spread in observed values. The distinctive source distribution (land/sea), the short lifetime and distance from source of ${ }^{210} \mathrm{~Pb}$ is reflected by the much better spatial correlation $(0.6-0.7)$ than in the case of ${ }^{7} \mathrm{Be}(0.2-0.4)$. The correlation of ${ }^{210} \mathrm{~Pb}$ concentrations is slightly better than that of deposition flux, but the RMSE is slightly greater. This suggests a more accurate spatial distribution of concentrations, although the actual departures from observations are slightly larger than in deposition flux. The situation is opposite in case of ${ }^{7} \mathrm{Be}$. Spatial correlation is lower for concentrations, and RMSE larger than in the case of deposition flux. In terms of RMSE the model performs better simulating ${ }^{7} \mathrm{Be}$ than ${ }^{210} \mathrm{~Pb}$ deposition, and the RMSE for concentrations is similar. The differences between resolutions are fairly small. There is a tendency of T42L39 to perform slightly worse than other resolutions, confirming the importance of a high vertical resolution.

\section{Budgets and residence times}

Model resolution is likely to influence the horizontal and vertical dispersion of ${ }^{10} \mathrm{Be}$ in the atmosphere and consequently the level of smoothing the large ${ }^{10} \mathrm{Be}$ production gradients in the stratosphere. This is best inspected by looking at atmospheric burdens (total integrated contents) of ${ }^{10} \mathrm{Be}$ and its stratospheric and tropospheric residence times. The residence times are averages for each atmospheric compartment, calculated by dividing the burden with the flux. These are summarised in Table 2. We see that there are significant differences in the absolute fluxes between the resolutions but the relative shares of production between the stratosphere and the troposphere as well as the wet to total deposition are relatively stable. The difference in absolute production rate between resolutions is caused by the relatively coarse horizontal and vertical resolution of the original source function by Masarik and Beer (2009). We applied spline interpolation to avoid stepwise changes in the source. 
Table 2. Globally integrated budgets and residence times of ${ }^{10} \mathrm{Be},{ }^{7} \mathrm{Be}$ and ${ }^{210} \mathrm{~Pb}$ at different model resolutions (1998-2002 mean). str=stratosphere, $\operatorname{tr}=$ troposphere. $(\%$ of total) shows the share of total deposition.

\begin{tabular}{|c|c|c|c|c|c|}
\hline & T63L47 & T63L31 & T42L31 & T42L39 & T21L19 \\
\hline \multicolumn{6}{|l|}{${ }^{10} \mathrm{Be}$} \\
\hline Production (str) & $0.127 \mathrm{~g} \mathrm{~d}^{-1}(66 \%)$ & $0.134 \mathrm{~g} \mathrm{~d}^{-1}(67 \%)$ & $0.135 \mathrm{~g} \mathrm{~d}^{-1}(67 \%)$ & $0.132 \mathrm{~g} \mathrm{~d}^{-1}(68 \%)$ & $0.144 \mathrm{~g} \mathrm{~d}^{-1}(69 \%)$ \\
\hline Production (tr) & $0.066 \mathrm{~g} \mathrm{~d}^{-1}$ & $0.066 \mathrm{~g} \mathrm{~d}^{-1}$ & $0.067 \mathrm{~g} \mathrm{~d}^{-1}$ & $0.062 \mathrm{~g} \mathrm{~d}^{-1}$ & $0.065 \mathrm{~g} \mathrm{~d}^{-1}$ \\
\hline Wet deposition (\% of total) & $0.184 \mathrm{~g} \mathrm{~d}^{-1}(94 \%)$ & $0.192 \mathrm{~g} \mathrm{~d}^{-1}(94 \%)$ & $0.192 \mathrm{~g} \mathrm{~d}^{-1}(95 \%)$ & $0.183 \mathrm{~g} \mathrm{~d}^{-1}(93 \%)$ & $0.185 \mathrm{~g} \mathrm{~d}^{-1}(93 \%)$ \\
\hline Dry deposition (\% of total) & $0.009 \mathrm{~g} \mathrm{~d}^{-1}(4 \%)$ & $0.009 \mathrm{~g} \mathrm{~d}^{-1}(5 \%)$ & $0.009 \mathrm{~g} \mathrm{~d}^{-1}(4 \%)$ & $0.009 \mathrm{~g} \mathrm{~d}^{-1}(5 \%)$ & $0.010 \mathrm{~g} \mathrm{~d}^{-1}(5 \%)$ \\
\hline Sedimentation (\% of total) & $0.003 \mathrm{~g} \mathrm{~d}^{-1}(2 \%)$ & $0.003 \mathrm{~g} \mathrm{~d}^{-1}(2 \%)$ & $0.004 \mathrm{~g} \mathrm{~d}^{-1}(2 \%)$ & $0.004 \mathrm{~g} \mathrm{~d}^{-1}(2 \%)$ & $0.005 \mathrm{~g} \mathrm{~d}^{-1}(2 \%)$ \\
\hline Burden (str) & $40.8 \mathrm{~g}$ & $47.3 \mathrm{~g}$ & $46.8 \mathrm{~g}$ & $39.9 \mathrm{~g}$ & $44.3 \mathrm{~g}$ \\
\hline Burden (tr) & $3.6 \mathrm{~g}$ & $3.9 \mathrm{~g}$ & $4.1 \mathrm{~g}$ & $4.0 \mathrm{~g}$ & $4.8 \mathrm{~g}$ \\
\hline Residence time (str) & $321 \mathrm{~d}$ & $364 d$ & $346 \mathrm{~d}$ & $302 \mathrm{~d}$ & $308 \mathrm{~d}$ \\
\hline Residence time (tr) & $18 \mathrm{~d}$ & $19 \mathrm{~d}$ & $20 \mathrm{~d}$ & $20 \mathrm{~d}$ & $24 \mathrm{~d}$ \\
\hline \multicolumn{6}{|l|}{${ }^{7} \mathrm{Be}$} \\
\hline Production (str) & $0.186 \mathrm{~g} \mathrm{~d}^{-1}(70 \%)$ & $0.204 \mathrm{~g} \mathrm{~d}^{-1}(72 \%)$ & $0.207 \mathrm{~g} \mathrm{~d}^{-1}(72 \%)$ & $0.193 \mathrm{~g} \mathrm{~d}^{-1}(72 \%)$ & $0.219 \mathrm{~g} \mathrm{~d}^{-1}(74 \%)$ \\
\hline Production (tr) & $0.080 \mathrm{~g} \mathrm{~d}^{-1}$ & $0.081 \mathrm{~g} \mathrm{~d}^{-1}$ & $0.082 \mathrm{~g} \mathrm{~d}^{-1}$ & $0.076 \mathrm{~g} \mathrm{~d}^{-1}$ & $0.078 \mathrm{~g} \mathrm{~d}^{-1}$ \\
\hline Decay & $0.167 \mathrm{~g} \mathrm{~d}^{-1}$ & $0.188 \mathrm{~g} \mathrm{~d}^{-1}$ & $0.189 \mathrm{~g} \mathrm{~d}^{-1}$ & $0.172 \mathrm{~g} \mathrm{~d}^{-1}$ & $0.193 \mathrm{~g} \mathrm{~d}^{-1}$ \\
\hline Wet deposition (\% of total) & $0.094 \mathrm{~g} \mathrm{~d}^{-1}(94 \%)$ & $0.094 \mathrm{~g} \mathrm{~d}^{-1}(94 \%)$ & $0.095 \mathrm{~g} \mathrm{~d}^{-1}(94 \%)$ & $0.092 \mathrm{~g} \mathrm{~d}^{-1}(94 \%)$ & $0.094 \mathrm{~g} \mathrm{~d}^{-1}(93 \%)$ \\
\hline Dry deposition (\% of total) & $0.004 \mathrm{~g} \mathrm{~d}^{-1}(4 \%)$ & $0.004 \mathrm{~g} \mathrm{~d}^{-1}(4 \%)$ & $0.004 \mathrm{~g} \mathrm{~d}^{-1}(4 \%)$ & $0.004 \mathrm{~g} \mathrm{~d}^{-1}(4 \%)$ & $0.005 \mathrm{~g} \mathrm{~d}^{-1}(5 \%)$ \\
\hline Sedimentation (\% of total) & $0.002 \mathrm{~g} \mathrm{~d}^{-1}(2 \%)$ & $0.002 \mathrm{~g} \mathrm{~d}^{-1}(1 \%)$ & $0.002 \mathrm{~g} \mathrm{~d}^{-1}(2 \%)$ & $0.002 \mathrm{~g} \mathrm{~d}^{-1}(2 \%)$ & $0.002 \mathrm{~g} \mathrm{~d}^{-1}(1 \%)$ \\
\hline Burden (str) & $11.1 \mathrm{~g}$ & $12.6 \mathrm{~g}$ & $12.6 \mathrm{~g}$ & $11.2 \mathrm{~g}$ & $12.5 \mathrm{~g}$ \\
\hline Burden (tr) & $1.8 \mathrm{~g}$ & $1.9 \mathrm{~g}$ & $1.9 \mathrm{~g}$ & $2.0 \mathrm{~g}$ & $2.4 \mathrm{~g}$ \\
\hline Residence time (str) & $59 \mathrm{~d}$ & $62 \mathrm{~d}$ & $61 \mathrm{~d}$ & $58 \mathrm{~d}$ & $57 \mathrm{~d}$ \\
\hline Residence time (tr) & $18 \mathrm{~d}$ & $19 \mathrm{~d}$ & $19 \mathrm{~d}$ & $20 \mathrm{~d}$ & $23 \mathrm{~d}$ \\
\hline \multicolumn{6}{|l|}{${ }^{210} \mathrm{~Pb}$} \\
\hline Production & $34.8 \mathrm{~g} \mathrm{~d}^{-1}$ & $34.8 \mathrm{~g} \mathrm{~d}^{-1}$ & $34.1 \mathrm{~g} \mathrm{~d}^{-1}$ & $33.5 \mathrm{~g} \mathrm{~d}^{-1}$ & $34.8 \mathrm{~g} \mathrm{~d}^{-1}$ \\
\hline Wet deposition (\% of total) & $33.1 \mathrm{~g} \mathrm{~d}^{-1}(95 \%)$ & $33.1 \mathrm{~g} \mathrm{~d}^{-1}(95 \%)$ & $32.3 \mathrm{~g} \mathrm{~d}^{-1}(95 \%)$ & $31.8 \mathrm{~g} \mathrm{~d}^{-1}(95 \%)$ & $32.5 \mathrm{~g} \mathrm{~d}^{-1}(94 \%)$ \\
\hline Dry deposition (\% of total) & $1.5 \mathrm{~g} \mathrm{~d}^{-1}(4 \%)$ & $1.5 \mathrm{~g} \mathrm{~d}^{-1}(4 \%)$ & $1.5 \mathrm{~g} \mathrm{~d}^{-1}(4 \%)$ & $1.3 \mathrm{~g} \mathrm{~d}^{-1}(5 \%)$ & $1.6 \mathrm{~g} \mathrm{~d}^{-1}(5 \%)$ \\
\hline Sedimentation (\% of total) & $0.3 \mathrm{gd}^{-1}(1 \%)$ & $0.3 \mathrm{~g} \mathrm{~d}^{-1}(1 \%)$ & $0.3 \mathrm{gd}^{-1}(1 \%)$ & $0.3 \mathrm{~g} \mathrm{~d}^{-1}(1 \%)$ & $0.4 \mathrm{~g} \mathrm{~d}^{-1}(1 \%)$ \\
\hline Burden (str) & $54.9 \mathrm{~g}$ & $63.3 \mathrm{~g}$ & $75.9 \mathrm{~g}$ & $77.7 \mathrm{~g}$ & $86.3 \mathrm{~g}$ \\
\hline Burden (tr) & $154.6 \mathrm{~g}$ & $160.9 \mathrm{~g}$ & $166.0 \mathrm{~g}$ & $179.6 \mathrm{~g}$ & $195.3 \mathrm{~g}$ \\
\hline Residence time (tr) & $4 \mathrm{~d}$ & $5 \mathrm{~d}$ & $5 \mathrm{~d}$ & $5 \mathrm{~d}$ & $6 \mathrm{~d}$ \\
\hline
\end{tabular}

The main difference is found to be due to vertical rather than to horizontal resolution. T42L39 and T21L19 with coarser vertical resolution predict a shorter stratospheric residence time for ${ }^{10} \mathrm{Be}$ by up to a month. The typical lag found between ${ }^{10} \mathrm{Be}$ deposition and cosmic ray production is in the order of $1 \mathrm{yr}$ (e.g. Pedro et al., 2011). This is somewhat shorter than the typical age of air in polar stratosphere of 3-5 yr (e.g. Waugh and Hall, 2002) due to the high production of ${ }^{10} \mathrm{Be}$ there, shortening the mean residence time. The runs with a higher vertical resolution produce a residence time closer to the observed estimate of $1 \mathrm{yr}$ (e.g. Pedro et al., 2011). There seems to be a clear link between the horizontal resolution and the tropospheric residence time of ${ }^{10} \mathrm{Be}$ (T63: $18 \mathrm{~d}, \mathrm{~T} 42: 20 \mathrm{~d}$, T21: $24 \mathrm{~d}$ ). The differences in the residence times are directly reflected in the stratospheric and tropospheric burdens. The coarse vertical resolution decreases the stratospheric residence time (T42L39 and T21L19), probably due to vertical diffusion. On the other hand, both middle atmosphere resolutions (T63L47, fine and T42L39, coarse) have a reduced stratospheric burden suggesting that stratosphere-troposphere exchange is more efficient in the middle atmosphere versions. This can be seen in Fig. 8: the stratospheric burdens of ${ }^{10} \mathrm{Be}$ are lower in the middle atmospheric versions (T63L47 and T42L39). The tropospheric burden is more influenced by the horizontal resolution. The highest concentrations at all tropospheric levels are found in the coarsest version (T21L19) and the concentrations decrease with increasing resolution.

In case of ${ }^{7} \mathrm{Be}$ these differences are dampened by the radioactive decay, especially in the stratosphere. The typical residence time of $>300$ days is significantly longer than the half-life of ${ }^{7} \mathrm{Be}$ (53.2 days) so that any effects of model resolution on stratospheric transport have little effect on its lifetime. In the troposphere the influence of the decay is less important due to the short residence of ca. 20 days. ${ }^{210} \mathrm{~Pb}$ is only produced in the troposphere and is removed rapidly, 


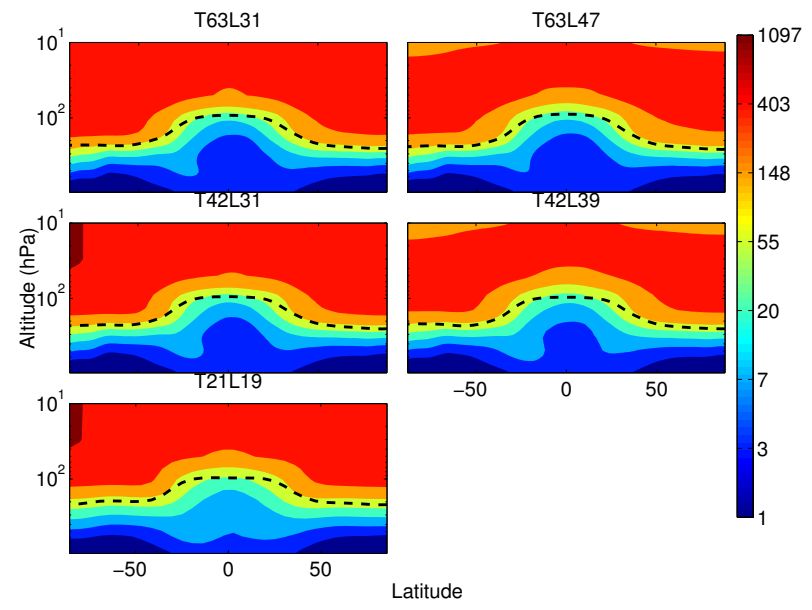

Fig. 8. Zonal mean air concentrations of ${ }^{10} \mathrm{Be}$ atoms $\left(10^{4} \mathrm{~m}^{-3}\right)$ with different resolutions. Tropopause pressure is highlighted in black. The altitude is shown only until $10 \mathrm{hPa}$ with the middle atmosphere versions (L39 and L47).

after 5 days on average. A few of the ${ }^{210} \mathrm{~Pb}$ atoms make it to the stratosphere where they can reside significantly longer than in the troposphere, increasing the relative fraction of stratospheric burden.

Figure 9 illustrates the zonal mean column densities of ${ }^{10} \mathrm{Be}$ atoms $\left(\mathrm{m}^{-2}\right)$ in the stratosphere and the troposphere for all resolutions. The resolutions T21L19, T42L39 and T63L47 are quite similar, whereas the T42L31 and T63L 31 resolutions predict more ${ }^{10} \mathrm{Be}$ in the high latitude stratosphere. The coarse T21L19 smooths most the latitude gradient. Larger changes can be observed in the troposphere. The largest amplitude variation over latitude is produced by the T42L39 resolution whereas the least change between latitudes is found in the T63L31 and T63L47 runs. The ${ }^{7} \mathrm{Be}$ surface observations (Figs. 2 and 7) seem to support a flatter gradient over latitude, yet this result should be interpreted with care due to their inhomogeneous spatial distribution.

\section{Mixing and transport path of ${ }^{10} \mathrm{Be}$}

Comparison with observations did not reveal significant differences in model performance between resolutions. However, the burdens and residence times indicated that the mixing of the ${ }^{10} \mathrm{Be}$ production gradient in the stratosphere is influenced by the model resolution. Here we make use of the divided production of ${ }^{10} \mathrm{Be}$ in the 30-degree bands in the stratosphere and the troposphere to study the actual transport path of ${ }^{10} \mathrm{Be}$ atoms from the stratosphere to the surface. As ${ }^{10} \mathrm{Be}$ produced in each of the atmospheric compartments was defined as separate tracers, they can be analysed individually. The shares of production in each atmospheric compartment are similar in each model run despite of the differences in resolutions: Stratosphere: $60-90^{\circ} \mathrm{S}(9.5-11.4 \%), 30-60^{\circ} \mathrm{S}$
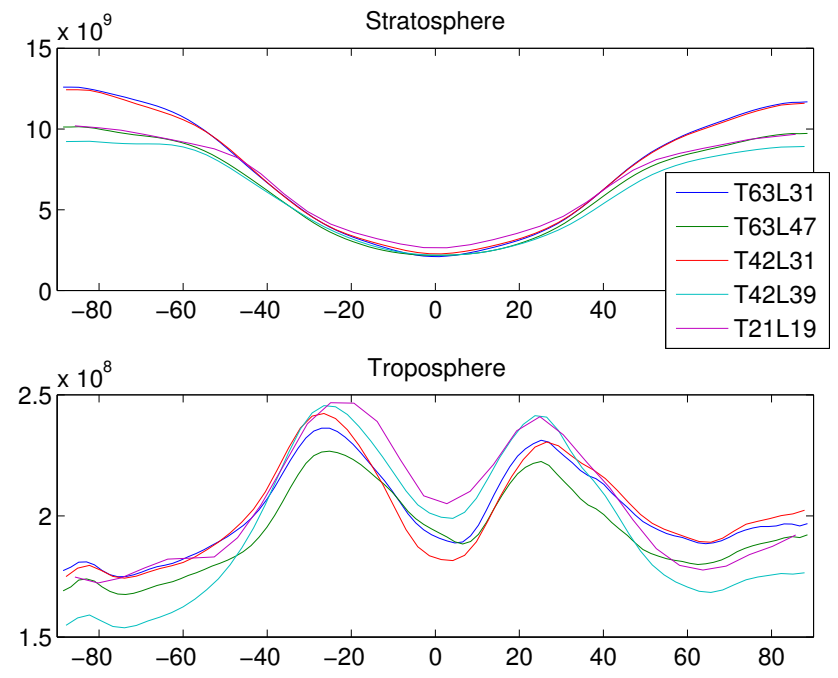

Fig. 9. Zonal mean stratospheric and tropospheric column density of ${ }^{10} \mathrm{Be}$ atoms (concentration integrated over the atmospheric column $\mathrm{m}^{-2}$ ) with different model resolutions.

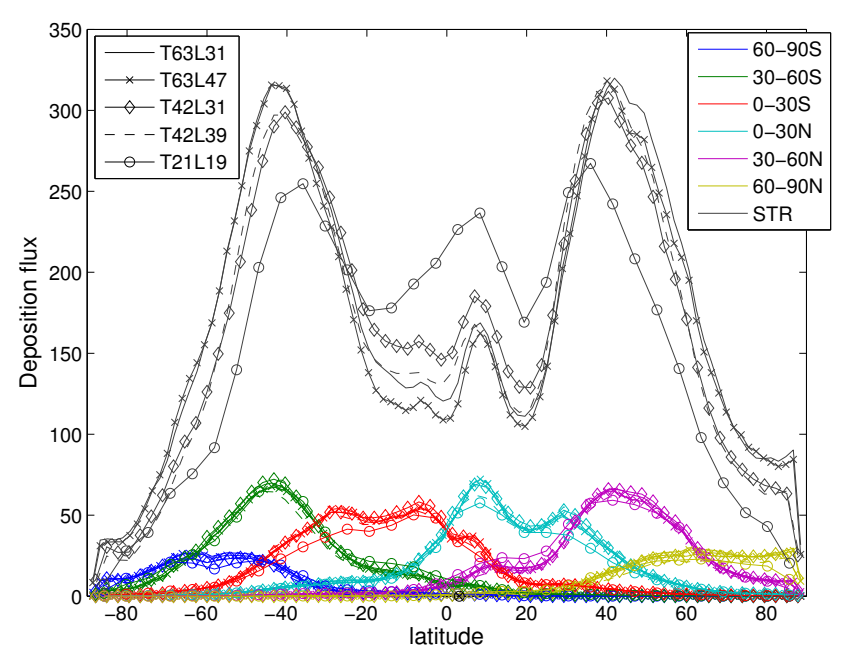

Fig. 10. Zonal mean deposition flux of ${ }^{10} \mathrm{Be}$ atoms $\left(\mathrm{m}^{-2} \mathrm{~s}^{-1}\right)$ with different resolutions. Fluxes of ${ }^{10} \mathrm{Be}$ produced in different atmospheric compartments are shown separately (stratosphere (STR) and the 30-degree latitude bands in the troposphere).

(17.3-19.3\%), 0-30 $\mathrm{S}(5.2-6.0 \%), 0-30^{\circ} \mathrm{N}(5.1-5.8 \%)$, $30-60^{\circ} \mathrm{N}(16.4-19.0 \%)$ and $60-90^{\circ} \mathrm{S}(10.2-11.7 \%)$, Troposphere: $60-90^{\circ} \mathrm{S}(1.7-1.9 \%), 30-60^{\circ} \mathrm{S}(5.6-6.5 \%), 0$ $30^{\circ} \mathrm{S}(7.4-8.6 \%), 0-30^{\circ} \mathrm{N}(7.4-8.6 \%), 30-60^{\circ} \mathrm{N}(5.7-$ $6.6 \%)$ and $60-90^{\circ} \mathrm{S}(1.6-2.0 \%)$. Figure 10 shows zonal mean deposition fluxes divided into the 30-degree bands in the troposphere and the whole stratosphere separately for all resolutions. All resolutions agree that the main contribution to deposition flux is the stratospheric ${ }^{10} \mathrm{Be}$, which enters the troposphere at mid-latitudes $\left(30-50^{\circ} \mathrm{N}\right.$ or $\left.\mathrm{S}\right)$ where most of it is also deposited. This can be seen by comparing air concentrations and deposition flux of ${ }^{10} \mathrm{Be}$ from all 
stratospheric compartments which all peak at mid-latitudes near the tropopause region. There is a secondary peak in the $\mathrm{NH}$ tropics due to the maximum precipitation rate there. ${ }^{10} \mathrm{Be}$ produced in the tropospheric polar latitudes $\left(60-90^{\circ}\right)$ is equally deposited between $40^{\circ}$ and $90^{\circ}$. Due to the minimum tropopause height over polar regions and the smallest surface area the contribution of ${ }^{10} \mathrm{Be}$ produced in polar troposphere to total deposition is the lowest. The contributions of the mid-latitude and tropical tropospheric ${ }^{10} \mathrm{Be}$ are similar. The mid-latitude tropospheric ${ }^{10} \mathrm{Be}$ is mostly deposited locally but reaches over the full hemisphere. The tropical ${ }^{10} \mathrm{Be}$ is spread over latitudes from 0 to $50^{\circ}$. Only a small part of it (ca. $5 \%$ ) is transported to the opposite hemisphere.

The differences between the five model runs in the troposphere are small, only the fluxes from the T21L19 being slightly lower at low and mid-latitudes. In the stratosphere the differences become remarkable. The results from the T42L31 and T42L39 are similar except for the slightly lower values from the T42L39 in the tropics due to the higher stratospheric contribution there. In the T21L19 run the signal is spread over latitudes from $50^{\circ} \mathrm{S}$ to $50^{\circ} \mathrm{N}$ with the tropical peak nearly as large as the midlatitude peaks. The T63L47 and T63L31 runs produce the opposite behaviour with the mid-latitude peaks being a factor of 3 larger than the tropical peaks. The results from the T42L31 and T42L39 runs are close to those of the T63L47/T63L31 runs but their horizontal spread at high latitudes is reduced. The horizontal diffusion in the results from the T21L19 is probably overestimated smearing out the ${ }^{10} \mathrm{Be}$ gradients in the mid- and low latitudes. This is in agreement with previous findings by Aghedo et al. (2010) who found weaker meridional transport at coarse resolutions, allowing for more diffusion towards low latitudes.

Figure 11 shows the stratospheric ${ }^{10} \mathrm{Be}$ divided into the 30-degree bands. The tropospheric fluxes are also shown for comparison. All resolutions agree that the stratospheric ${ }^{10} \mathrm{Be}$, from all latitudes, is transported into the troposphere via the latitudes $30-50^{\circ} \mathrm{N}$ or $\mathrm{S}$. The stratospheric polar ${ }^{10} \mathrm{Be}$ which is most strongly modulated by solar activity contributes to a smaller fraction of total deposition than the stratospheric mid-latitude production. This is due to the very small surface area of the Earth poleward of $60^{\circ}$. Comparing the deposition from $60-90^{\circ}$ stratosphere with that from $60-90^{\circ}$ troposphere we see that the stratospheric part is larger at all latitudes, except polewards from $80^{\circ}$ where the fractions are equally large. At midlatitudes the stratospheric part always dominates. The tropical ${ }^{10} \mathrm{Be}$ flux is dominated by the tropospheric part. The smearing of the stratospheric ${ }^{10} \mathrm{Be}$ signal towards low latitudes by T21L19 is visible at all source latitudes. The comparison with air concentrations of stratospheric ${ }^{10} \mathrm{Be}$ near the tropopause, which also peak at midlatitudes, suggests that the smearing takes place in the troposphere after the ${ }^{10} \mathrm{Be}$ has been transported from the stratosphere. Figure 8 supports this by showing the increased concentrations in the low latitude troposphere by T21L19 compared with other resolutions. Similar behaviour by the
Zonal mean deposition flux

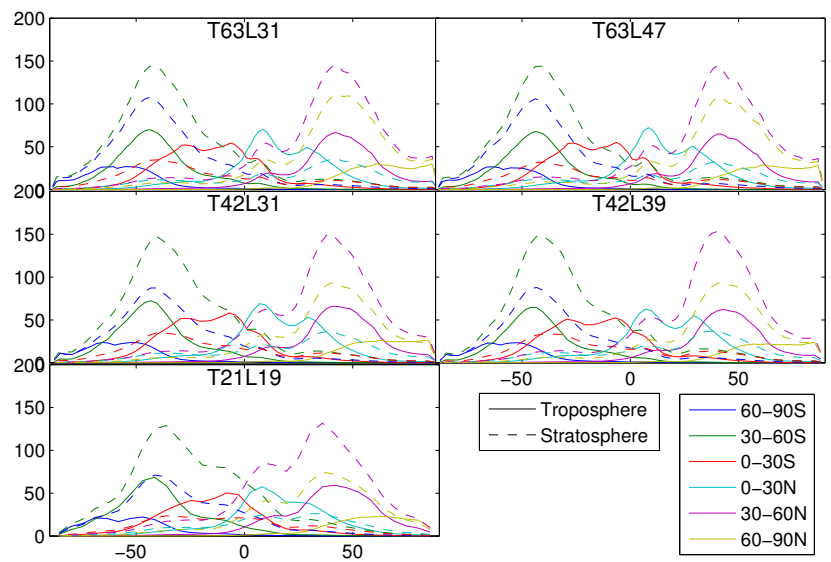

Fig. 11. Zonal mean deposition flux of ${ }^{10} \mathrm{Be}$ atoms $\left(\mathrm{m}^{-2} \mathrm{~s}^{-1}\right)$ with different resolutions. Fluxes of ${ }^{10} \mathrm{Be}$ produced in different atmospheric compartments are shown separately (30-degree latitude bands in the stratosphere and the troposphere).

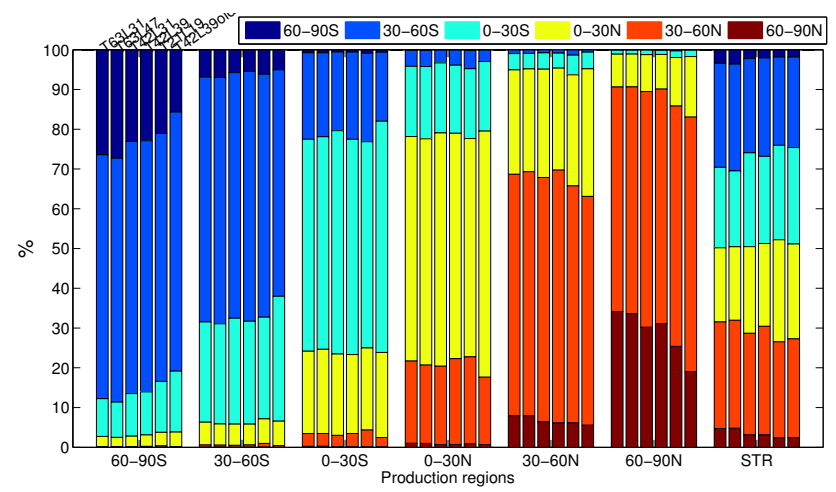

Fig. 12. Percentages of ${ }^{10} \mathrm{Be}$ deposited at a given latitude ('Deposition region' shown in the legend) which were produced at the tropospheric latitudes indicated on the x-axis ('Production region'). Also shown is stratospheric (STR) production, averaged across all latitudes. The five bars at each latitude band show the model resolutions "T63L47”, "T42L39”, “T42L31", “T21L19” as well as the “T42L39old”, published in Heikkilä et al. (2009), respectively.

ECHAM5 model has been reported by Aghedo et al. (2010) who found that meridional transport was decreased at coarse resolution, leading to increased concentrations of surface tracers in the tropics.

The exact "fate" of ${ }^{10} \mathrm{Be}$ produced at a given latitude is illustrated in Fig. 12, adapted from Fig. 8 of Heikkilä et al. (2009). The $\mathrm{x}$-axis shows the origin of ${ }^{10} \mathrm{Be}$, i.e. at which tropospheric latitude $\left(60-90,30-60,0-30^{\circ} \mathrm{N}\right.$ or $\left.\mathrm{S}\right)$ or (the entire) stratosphere it was produced. The colours indicate the latitude where the ${ }^{10} \mathrm{Be}$ is deposited. The $\mathrm{y}$-axis shows the percentage of ${ }^{10} \mathrm{Be}$ produced at the latitude (given by the $\mathrm{x}$-axis) which is deposited at a given latitude band (legend). The fractions of deposition were calculated weighted 
with the area of the Earth within each latitude band. The five bars show the model resolutions "T63L31", "T63L47", "T42L39", "T42L31" and "T21L19". Additionally the original results presented in Heikkilä et al. (2009) are also shown ("T42L39old"). Note that for the previous results an older version of the ECHAM5-HAM model was used, the production calculations were based on Masarik and Beer (1999) and not the updated ones by Masarik and Beer (2009), the years simulated were 1986-1990 instead of the 1998-2002 and the simulations were performed on a NEC SX-6 cluster whereas a SUN cluster was used for the current simulations. None of these differences is expected to be large but their combination might cause changes in results. There are rather small differences between the resolutions in ${ }^{10} \mathrm{Be}$ produced at low and mid-latitudes as well as the stratosphere. The main difference occurs at polar tropospheric ${ }^{10} \mathrm{Be}$. The coarsest resolution investigated in this study, T21L19, is actually closest to the previous results. Notably the fraction of locally deposited ${ }^{10} \mathrm{Be}$ is increased, being the largest with the finest resolution (T63L47). The mid-latitude fractions are similar but the tropical part is consequently reduced. This shows that in the finest resolution the horizontal dispersion of ${ }^{10} \mathrm{Be}$ is the most limited. The difference between the polar tropospheric ${ }^{10} \mathrm{Be}$ in the "old" and the "new" T42L39 is approximately $10 \%$ (north) and 5\% (south). It has to be kept in mind that the polar tropospheric production only contributes some $4 \%$ to total production. A similar pattern, although less pronounced can be seen at mid- and low latitudes as well. The "old" and "new" results vary less with the stratospheric ${ }^{10} \mathrm{Be}$ which is the main component of the total deposition. The highest resolution (T63L47) deposits the most of stratospheric ${ }^{10} \mathrm{Be}$ at mid-latitudes, more in the polar regions and less at low latitudes than other resolutions.

These results suggest that there is remarkable variability between model resolutions but also between the realisations of model experiments. It helps us to get a grip of the uncertainty and to what extent the results can be interpreted. All models agree that the stratospheric fraction is the dominant one in deposition flux and that its main transport path into the troposphere is via the latitudes $30^{\circ}$ to $50^{\circ}$. The largest variability was found in the ${ }^{10} \mathrm{Be}$ produced in the polar troposphere likely due to the fact that it is the smallest fraction in absolute numbers. The finest model resolution suggests the least horizontal dispersion over latitudes in this study. This seems to be a typical feature of the ECHAM model. Model inter-comparison of the total aerosol load showed that horizontal dispersion by ECHAM indeed belongs to the lower end of the range (Textor et al., 2006). This behaviour by the ECHAM is even strengthened by the use of a higher resolution which can be assumed to improve the model performance. Unfortunately these results cannot be validated with observations.

\section{Summary and conclusions}

This study addressed the question to what extent the atmospheric transport of the solar proxy ${ }^{10} \mathrm{Be}$ is model resolution dependent. Understanding the level of mixing of ${ }^{10} \mathrm{Be}$ characterised by the strong latitude and altitude gradients in its production rate is essential in order to correctly interpret the observed variability in natural archives. While the different model resolutions are capable of reproducing the magnitude of the observations the number of observations is too limited to explicitly rate model performance. In this study we compare model simulations run on different horizontal and vertical resolutions, with or without middle atmosphere configurations. The resolutions used were the T63L47, with a fine horizontal and fine vertical resolution, including the middle atmosphere up to ca. $80 \mathrm{~km}$, the T63L31, a fine horizontal and vertical resolution, only including the lower stratosphere up to ca. $30 \mathrm{~km}$, the T42L39, the commonly used resolution for ${ }^{10} \mathrm{Be}$ studies with ECHAM5-HAM with an average horizontal and coarse vertical resolution including the middle atmosphere, the T42L31, including the lower stratosphere up to ca. $30 \mathrm{~km}$ but with a fine vertical resolution, and the T21L19, a coarse horizontal and vertical resolution up to ca. $30 \mathrm{~km}$. The years analysed were 1998-2002.

The model runs were first validated against a set of observed ${ }^{7} \mathrm{Be}$ and ${ }^{210} \mathrm{~Pb}$ surface air concentration and ${ }^{7} \mathrm{Be}$, ${ }^{210} \mathrm{~Pb}$ and ${ }^{10} \mathrm{Be}$ deposition fluxes. All resolutions used produced comparable values with observations. The spatial coverage of observations is limited and the spread between observations located near each other was much larger than between model resolutions. The fine horizontal and vertical resolution run (T63L47) produced the flattest meridional gradient in ${ }^{7} \mathrm{Be}$ air concentrations. The observations point to a weaker meridional gradient but it might only be the case at the locations where observations exist. However, this remains to be confirmed when more observations are available.

The production rate of ${ }^{10} \mathrm{Be}$ was divided into 30-degree latitude bands for these simulations in order to assess the actual mixing and transport path of ${ }^{10} \mathrm{Be}$ produced in different atmospheric compartments. All model resolutions agreed that the main contributor to deposition is the stratospheric ${ }^{10} \mathrm{Be}$ input, which enters the troposphere at latitudes 30 $50^{\circ} \mathrm{N}$ and S. Significant differences were found in the dispersion of ${ }^{10} \mathrm{Be}$ in the troposphere before deposition. The coarse model resolution T21L19 produced the most horizontal dispersion whereas the fine T63L47 showed the least. The tropospheric residence time by the T21L19 was also longer (24 days instead of the 18 days by T63L47). The residence times in the stratosphere were significantly longer by the fine vertical resolution runs, even with the one not including the middle atmosphere. Despite of these differences the global budgets, fractions of wet and dry deposition of total and stratospheric to tropospheric production were similar in all runs.

Relatively large differences were found between model configurations in the percentages of the origin (produced in 
the 30-degree latitude compartments of the stratosphere or the troposphere) of ${ }^{10} \mathrm{Be}$ deposition flux. This is due to different degree of atmospheric mixing simulated by the five model resolutions. The fine resolution models produced a larger fraction of local tropospheric deposition at polar latitudes than the coarse ones. However, the ${ }^{10} \mathrm{Be}$ production in the polar troposphere contributes the least (ca. 4\%) to total production and therefore does not significantly affect production variability. The contributions of ${ }^{10} \mathrm{Be}$ production from stratospheric or tropospheric mid- or low latitude compartments to deposition differed less across different model configurations. Here the differences arose from the horizontal resolution. When looking at the distributions of surface air concentrations or deposition fluxes the main differences were caused by the vertical resolution. In terms of atmospheric mixing of ${ }^{10} \mathrm{Be}$ there seemed to be little difference between the T63L47 and T63L31, or the T42L39 and T42L31 resolutions. The use of the finer vertical resolution may be more beneficial than the middle atmosphere configuration at the cost of vertical resolution, as no significant improvement of surface air concentrations, stratospheric residence time, horizontal or vertical mixing was found when the middle atmosphere version was used.

Acknowledgements. The authors would like to thank Greg Doherty for helping to install the ECHAM5-HAM model. This work was supported by an award under the Merit Allocation Scheme on the NCI National Facility at the ANU.

Edited by: J. Kaiser

\section{References}

Aghedo, A. M., Rast, S., and Schultz, M. G.: Sensitivity of tracer transport to model resolution, prescribed meteorology and tracer lifetime in the general circulation model ECHAM5, Atmos. Chem. Phys., 10, 3385-3396, doi:10.5194/acp-10-3385-2010, 2010.

Al-Azmi, D., Sayed, A. M. and Yatim, H. A., Variations in ${ }^{7}$ Be concentrations in the atmosphere of Kuwait during period 1994 to 1998, Appl. Radiat. Isot., 55, 413-417, 2001.

Baskaran, M., Coleman, C., and Santchi, P., Atmospheric depositional fluxes of ${ }^{7} \mathrm{Be}$ and ${ }^{210} \mathrm{~Pb}$ at Galveston and College Station, Texas, J. Geophys. Res., 98, 20555-20571, 1993.

Bleichrodt, J.: Mean tropospheric residence time of cosmic-rayproduced beryllium 7 at north temperate latitudes, J. Geophys. Res., 83, 3058-3062, 1978.

Brost, R., Feichter, J., and Heimann, M.: Three-dimensional simulation of ${ }^{7} \mathrm{Be}$ in a global climate model, J. Geophys. Res., 96, 22423-22445, 1991.

Brown, L., Stensland, G. J., Klein, J., and Middleton, R.: Atmospheric deposition of ${ }^{7} \mathrm{Be}$ and ${ }^{10} \mathrm{Be}$, Geochim. Cosmochim. Acta, 53, 135-142, 1988.

Cannizzaro, F., Greco, G., Raneli, M., Spitale, M. C., and Tomarchio, E.: Concentration measurements of ${ }^{7} \mathrm{Be}$ at ground level air at Palermo, Italy - comparison with solar activity over a period of 21 years, J. Environ. Radioac., 72, 259-271, 2004.

Chengde, S., Beer, J., Tungsheng, L., Oeschger, H., Bonani, G., Suter, M., and Wölfli, W., ${ }^{10} \mathrm{Be}$ in Chinese loess, Earth Planet. Sci. Lett., 109, 169-177, 1992.

Crecelius, E. A.; Prediction of marine atmospheric deposition rates using total ${ }^{7} \mathrm{Be}$ deposition velocities, Atmos. Environ., 15, 579582,1981

Dibb, J.: Atmospheric deposition of beryllium 7 in the Chesapeake Bay region, J. Geophys. Res., 94, 2261-2265, (1989)

Elsässer, C., Wagenbach, D., Weller, R., Auer, M., Wallner, A., and Christl, M., Continuous 25-yr aerosol records at coastal Antarctica, Part 2: variability of the radionuclides ${ }^{7} \mathrm{Be},{ }^{10} \mathrm{Be}$ and ${ }^{210} \mathrm{~Pb}$, Tellus, B63, 901-919, 2011.

Feichter, J., Brost, R. A., and Heimann, M.: Three-dimensional modeling of the concentration and deposition of ${ }^{210} \mathrm{~Pb}$ aerosols, J. Geophys. Res., 96, 22447-22460, 1991.

Gerasopoulos, E., Zanis, P., Stohl, A., Zerefos, C. S., Papastefanou, C., Ringer, W., Tobler, L., Hübener, S., Gäggeler, H. W., Kanter, H. J., Tositti, L., and Sandrini, S.: A climatology of ${ }^{7}$ Be at four high-altitude stations at the Alps and the Northern Apennines, Atmos. Environ., 35, 6347-6360, 2001.

Graham, I., Ditchburn, R., and Barry, B.: Atmospheric deposition of ${ }^{7} \mathrm{Be}$ and ${ }^{10} \mathrm{Be}$ in New Zealand rain (1996-1998), Geochim. Cosmochim. Acta, 67, 361-373, 2003.

Graustein, W. K. and Turekian, K. K., ${ }^{210} \mathrm{~Pb}$ and ${ }^{137} \mathrm{Cs}$ in Air and Soils Measure the Rate and Vertical Profile of Aerosol Scavenging, J. Geophys. Res., 91, 14355-14366, 1986.

Gray, S. L.: A case study of stratosphere to troposphere transport: The role of convective transport and the sensitivity to model resolution, J. Geophys. Res., 108, 4590, doi:10.1029/2002JD003317, 2003.

Hack, J. J., Caron, J. M., Danabasoglu, G. D., Oleson, K. W., Bitz, C., and Truesdale, J. E.: CCSM-CAM3 Climate Simulation Sensivity to Changes in Horizontal Resolution, J. Climate, 19, 2267 2289, doi:10.1175/JCLI3764.1, 2006.

Hagemann, S., Arpe, K., and Roeckner, E.: Evaluation of the hydrological cycle in the ECHAM5 model, J. Climate, 19, 3810-3827, 2006.

Hasebe, N., Doke, T., Kikuchi, J., Takeuchi, Y. and Sugiyama, T.: Observations of fallout rates of atmospheric ${ }^{7} \mathrm{Be}$ and ${ }^{22} \mathrm{Na}$ produced by cosmic rays - Concerning estimation of the fallout rate of atmospheric ${ }^{26} \mathrm{Al}$, J. Geophys. Res., 86, 520-524, 1981.

Heikkilä, U., Beer, J., and Alfimov, V.: ${ }^{10} \mathrm{Be}$ and ${ }^{7} \mathrm{Be}$ in precipitation in Dübendorf $(440 \mathrm{~m})$ and at Jungfraujoch $(3580 \mathrm{~m})$, Switzerland (1998-2005), J. Geophys. Res., 113, D11104, doi:10.1029/2007JD009160, 2008a.

Heikkilä, U., Beer, J., and Feichter, J.: Modelling cosmogenic radionuclides ${ }^{10} \mathrm{Be}$ and ${ }^{7} \mathrm{Be}$ during the Maunder Minimum with the ECHAM5-HAM general circulation model, Atmos. Chem. Phys., 8, 2797-2809, doi:10.5194/acp-8-2797-2008, 2008b.

Heikkilä, U., Beer, J., and Feichter, J.: Meridional transport and deposition of atmospheric ${ }^{10} \mathrm{Be}$, Atmos. Chem. Phys., 9, 515-527, doi:10.5194/acp-9-515-2009, 2009.

Hirose, K., Honda, T., Yagishita, S., Igarashi, Y., and Aoyama, M.: Deposition behaviours of ${ }^{210} \mathrm{~Pb},{ }^{7} \mathrm{Be}$ and thorium isotopes observed in Tsukuba and Nagasaki, Japan, Atmos. Environ., 38, 6601-6608, 2004. 
Huh, C.-A., Su, C.-C. and Shiau, L.-J.: Factors controlling temporal and spatial variations of atmospheric deposition of ${ }^{7} \mathrm{Be}$ and ${ }^{210} \mathrm{~Pb}$ in northern Taiwan, J. Geophys. Res., 111, D16304, doi:10.1029/2006JD007180, 2006.

Igarashi, Y., Hirose, K., and Otsuji-Hatori, M.: Beryllium-7 deposition and its relation to sulfate deposition, J. Atmos. Chem., 29, 217-231, 1998.

Knies, D. L.: Cosmogenic radionuclides in precipitation, Ph.D. dissertation, Purdue University, West Lafayette, Indiana, 1994.

Koch, D., Schmidt, G., and Field, C.: Sulfur, sea salt and radionuclide aerosols in GISS ModelE, J. Geophys. Res., 111, D06206, doi:10.1029/2004JD005550, 2006.

Kulan, A., Aldahan, A., Possnert, G., and Vintersved, I.: Distribution of ${ }^{7} \mathrm{Be}$ in surface air of Europe, Atmos. Environ., 40, 38553868, 2006.

Lal, D. and Peters, B.: Cosmic ray produced radioactivity on the Earth, Handbuch der Physik, XLVI/2, 551-612, Springer-Verlag, New York, USA, 1967.

Land, C., Feichter, J., and Sausen, R.: Impact of vertical resolution on the transport of passive tracers in the ECHAM4 model, Tellus, 54B, 344-360, 2002.

Liu, H., Jacob, D., Bey, I. and Yantosca, R.: Constraints from ${ }^{210} \mathrm{~Pb}$ and ${ }^{7} \mathrm{Be}$ on wet deposition and transport in a global threedimensional chemical tracer model driven by assimilated meteorological fields. J. Geophys. Res., 106, 12109-12128, 2001.

Masarik. J. and Beer, J.: Simulation of particle fluxes and cosmogenic nuclide production in the Earth's atmosphere, J. Geophys. Res., 104, 12099-12111, 1999.

Masarik, J. and Beer, J.: An updated simulation of particle fluxes and cosmogenic nuclide production in the Earth's atmosphere, J. Geophys. Res., 114, D11103, doi:10.1029/2008JD010557, 2009.

McNeary, D. and Baskaran, M.: Depositional charasteristics of ${ }^{7} \mathrm{Be}$ and ${ }^{210} \mathrm{~Pb}$ in southeastern Michigan, J. Geophys. Res., 108, 4210, doi:10.1029/2002JD003021, 2003.

Monaghan, M. C., Krishnaswami, S., and Turekian, K. K.: The global-average production of ${ }^{10} \mathrm{Be}$, Earth Planet. Sci. Lett., 76, 279-287, 1986.

Nijampurkar, V. N. and Clausen, H. B.: A century old record of lead-210 fallout on the Greenland ice sheet, Tellus, 42B, 29-38, 1990.

Olsen, C., Lowry, P., Cutshall, N., Todd, J., Wong, G., and Casey, W.: Atmospheric fluxes and marsh-soil inventories of ${ }^{7} \mathrm{Be}$ and ${ }^{210} \mathrm{~Pb}$, J. Geophys. Res., 90, 10487-10495, 1985.

Pacini, A. A., Usoskin, I. G., Evangelista, H., Echer, E., and de Paula, R., Cosmogenic isotope ${ }^{7} \mathrm{Be}$ : A case study of depositional processes in Rio de Janeiro in 2008-2009, Adv. Space Res., 48, 811-818, 2011.

Papastefanou, C. and Ioannidou, A., Beryllium-7 in ambient air, Environ. Int., 22, suppl. 1, S125-S130, 1996.

Pedro, J. B., Smith, A. M., Simon, K. J., van Ommen, T. D., and Curran, M. A. J.: High-resolution records of the beryllium-10 solar activity proxy in ice from Law Dome, East Antarctica: measurement, reproducibility and principal trends, Clim. Past, 7, 707-721, doi:10.5194/cp-7-707-2011, 2011.

Richter, J. H., Sassi, F., Garcia, R. R., Matthes, K., and Fischer, C. A., Dynamics of the middle atmosphere as simulated by the Whole Atmosphere Community Climate Model, version 3 (WACCM3), J. Geophys. Res., 113, D08101, doi:10.1029/2007JD009269, 2008.
Roeckner, E., Baeuml, G., Bonventura, L., Brokopf, R., Esch, M., Giorgetta, M., Hagemann, S., Kirchner, I., Kornblueh, L., Manzini, E., Rhodin, A., Schlese, U., Schulzweida, U., and Tompkins, A.: The atmospheric general circulation model ECHAM5. PART I: Model description, Report 349, Max Planck Institute for Meteorology, Hamburg, Germany, available at: http: //www.mpimet.mpg.de, 2003.

Roeckner, E., Brokopf, R., Esch, M., Giorgetta, M., Hagemann, S., Kornblueh, L., Manzini, E., Schlese, U., and Schulzweida, U.: Sensitivity of simulated climate to horizontal and vertical resolution in the ECHAM5 atmosphere model, J. Climate, 19, 37713791, doi:10.1175/JCLI3824.1, 2006.

Somayulu, B. L. K., Sharma, P., Beer, J., Bonani, G., Hofmann, H.-J., Morenzoni, E., Nessi, M., Suter, M., and Wölfli, W., ${ }^{10} \mathrm{Be}$ fallout in rains in India, Nucl. Inst. Methods Phys. B., 5, 398403, 1984.

Stier, P., Feichter, J., Kinne, S., Kloster, S., Vignati, E., Wilson, J., Ganzeveld, L., Tegen, I., Werner, M., Balkanski, Y., Schulz, M., Boucher, O., Minikin, A., and Petzold, A.: The aerosol-climate model ECHAM5-HAM, Atmos. Chem. Phys., 5, 1125-1156, doi:10.5194/acp-5-1125-2005, 2005.

Textor, C., Schulz, M., Guibert, S., Kinne, S., Balkanski, Y., Bauer, S., Berntsen, T., Berglen, T., Boucher, O., Chin, M., Dentener, F., Diehl, T., Easter, R., Feichter, J., Fillmore, D., Ghan, S., Ginoux, P., Gong, S., Grini, A., Hendricks, J., Horowitz, L., Huang, P., Isaksen, I., Iversen, T., Kloster, S., Koch, D., Kirkevåg, A., Kristjansson, J. E., Krol, M., Lauer, A., Lamarque, J. F., Liu, X., Montanaro, V., Myhre, G., Penner, J., Pitari, G., Reddy, S., Seland, Ø., Stier, P., Takemura, T.m and Tie, X., Analysis and quantification of the diversities of aerosol life cycles within AeroCom, Atmos. Chem. Phys., 6, 1777-1813, doi:10.5194/acp-61777-2006, 2006.

Todd, J., Wong, G., Olsen, C. and Larsen, I., Atmospheric depositional characteristics of beryllium 7 and lead 210 along the southerneast Virginia coast, J. Geophys. Res., 94, 11106-11116, (1989)

Turekian, K. K., Nozaki, Y and Benninger, L. K., Geochemistry of atmospheric radon and radon products, Ann. Rev. Earth Planet. Sci., 5, 227-255, 1977.

Turekian, K., Benninger, L., and Dion, E., ${ }^{7} \mathrm{Be}$ and ${ }^{210} \mathrm{~Pb}$ total deposition fluxes at New Haven, Connecticut and Bermuda, J. Geophys. Res., 88, 5411-5415, 1983.

Uematsu, M., Duce, R., and Prospero, J.: Atmosphere beryllium-7 concentrations over the Pacific Ocean, Geophys. Res. Lett., 21, 561-564, 1994.

van Velthoven, P. F. J. and Kelder, H.: Estimates of stratospheretroposphere exchange: Sensitivity to model formulation and horizontal resolution, J. Geophys. Res., 101, 1429-1434, 1996.

Waugh, D. W. and Hall, T. M.: Age of stratospheric air: Theory, observations and models, Rev. Geophys., 40, 1010, doi:10.1029/2000RG000101, 2002.

Young, J. and Silker, W.: Aerosol deposition velocities on the Pacific and Atlantic Oceans calculated from ${ }^{7} \mathrm{Be}$ measurements, Earth Planet. Sci. Lett., 50, 92-104, 1980. 